\begin{tabular}{|c|c|c|c|c|c|c|}
\hline $\begin{array}{l}\text { Butyl } \\
\text { series. }\end{array}$ & & $\frac{\text { At. wt. }}{2}$ & & Sp. gr. & & $\begin{array}{c}\text { Condensa- } \\
\text { tion. }\end{array}$ \\
\hline $\mathrm{C}_{4} \mathrm{H}_{10}$ & $\cdots$ & 29 & $\cdots$ & 0.600 & $\cdots$ & $23^{\circ} 7$ \\
\hline $\mathrm{C}_{5} \mathrm{H}_{12}$ & $\ldots$ & $3^{6}$ & ... & 0.628 & $\ldots$ & $192 \div 3$ \\
\hline $\mathrm{C}_{6} \mathrm{H}_{14}$ & $\ldots$ & 43 & $\ldots$ & 0.669 & $\ldots$ & $174^{\circ} 2$ \\
\hline $\mathrm{C}_{7} \mathrm{H}_{76}$ & $\cdots$ & $5^{\circ}$ & $\cdots$ & 0.699 & $\ldots$ & 156.6 \\
\hline $\mathrm{C}_{8} \mathrm{H}_{1 \mathrm{~s}}$ & $\ldots$ & 57 & $\ldots$ & 0.726 & ... & $142 \cdot 6$ \\
\hline $\mathrm{C}_{9} \mathrm{H}_{20}$ & $\ldots$ & 64 & $\cdots$ & $0.74 I$ & $\ldots$ & $132^{\circ} 9$ \\
\hline $\mathrm{C}_{10} \mathrm{H}_{22}$ & $\ldots$ & 71 & ... & 0.757 & ... & I $19^{\circ} 4$ \\
\hline $\mathrm{C}_{11} \mathrm{H}_{24}$ & $\cdots$ & 78 & $\cdots$ & 0.766 & $\ldots$ & $110^{\circ} 0$ \\
\hline $\mathrm{C}_{12} \mathrm{H}_{26}$ & $\cdots$ & 85 & $\cdots$ & $0.77^{8}$ & $\ldots$ & 102.5 \\
\hline $\mathrm{C}_{13} \mathrm{H}_{28}$ & $\ldots$ & 92 & $\ldots$ & 0.796 & $\cdots$ & $97^{\circ} 0$ \\
\hline 14 & $\cdots$ & 99 & ... & 0.809 & $\ldots$ & $9 I^{\prime} 5$ \\
\hline & $\ldots$ & 106 & $\ldots$ & 0.825 & $\ldots$ & $87^{\circ} 1$ \\
\hline
\end{tabular}

From this it will be seen that the amount of condensation of the gas, as it passes into the liquid state, becomes less and less as the molecular composition becomes more complex, and moreover, that the difference in amount of condensation of any two adjacent members of the series becomes diminished at the same time; thus the difference in condensation on passing from butyl hydride to amyl hydride is $39^{\circ} 4$; from myristyl to benyl only $4^{\circ} 4$ c.c. If the fact that the sp. gr. of these substances has been taken at a common temperature, instead of at their boiling points be considered, it will be seen that the difference is really less marked than it otherwise would be.

From the fact that an increase in the number of atoms in the molecules is accompanied by a decrease in condensation, it would appear that a substance might be found which should possess the same, or nearly the same, specific gravity in the state of gas and solid, i.e., in which these states should become identical. A large number of atoms would have to enter into the formation of a molecule to bring about this result, though if there be any truth in the formula for albumin quoted by Herbert Spencer on the authority of Mulder, it must be approached by this substance. This formula- $\mathrm{IO}\left(\mathrm{C}_{40} \mathrm{H}_{31} \mathrm{~N}_{5} \mathrm{O}_{12}\right)+\mathrm{S}_{2} \mathrm{P}$-gives us an atomic weight of 3912.5 , and if we assume the specific gravity of albumin to be 2 , this will give us-

$$
\frac{2}{3912} \times 11,200=5 \cdot 8 \text { about. }
$$

So that I c.c. of albumin, on this assumption, would be only about five times as heavy in the colloid as in the gaseous state. This fact may help to throw some light on the peculiar properties of colloids, and taken in conjunction with Herbert Spencer's reflections, on that most curious of all colloids :-protoplasm.

$$
\text { W. J. Sollas }
$$

\section{A Claim for Precedence}

IN reference to the notice of Favre in NATURE, vol. xxi. p. 4I 7 , I shall be obliged if you will kindly allow me space for a few remarks.

Credit for much valuable work is given justly to Favre, but I must be allowed to protest against having the few grains of corn belonging to others added to his well-filled granary. One of the discoveries ascribed to Favre in your notice is "the relative diminution in the heat evolved by the combination of a compound body compared with that due to the combustion of its varied constituents," or rather, the cause of it. Now he was not the discoverer of this, but I was. In October, I $85 \mathrm{r}$, I fub. lished in the Philosophical Magazine a paper proving that decomposition absorbs heat, and exactly to the same extent that the previous combination of the constituents had evolved it. I proved it by passing a galvanic current through water and finding the increase of temperature. This gave the heat produced by the resistance lessened by the decomposition of the water. Then, to find the heat of resistance undiminished by decomposition, I passed a similar current, as shown by a galvanometer, through a platinum wire offering the same resistance as the water, and surrounded by an equal quantity as in the first experiment. The difference of temperature in the two experiments was, of course, the heat absorbed by the decomposition.

In some twelve months or so after this publication, Favre and Silberman published in vol. xxxvii. of the Annales de Chimie et de Physique, p. 507, the very same experiment to prove the same principle, giving it as their own.

In 1852 a paper from me was read at the Belfast meeting of the British Association, and published the same year, in November, in the Philosophical Magazine, giving the first experiments made in thermo-chemistry in which decomposition is taken into account, and showing the principle by which the heat of com- bination of bodies can be known from that absorbed in their decomposition, and which has since been used in all thermochemical researches.

This principle and my experiments were published six months afterwards by Favre and Silberman (Annales de Chimie et de Physique, vol. xxxvii. p. 484) without allusion to me.

These publications and dates are easily to be referred to. It is no matter of opinion whether I should be looked on as the originator of thermo-chemistry as it at present stands, but it is a matter of fact that $I \mathrm{am}$, as can be proved by the references I have given; and I think I should not be acting wisely to allow the credit of much labour and thought which is due to myself to be given to another, at least without protest. I do not, of course, want to compare myself with Favre, but I certainly claim, and prior publication establishes for me, the discovery of the principle that originated all the thermo-chemistry of the day which is generally given to him; nor do I expect that I will ever be given as an authority as long as scientific men can quote the names of Favre and Silberman; but I ask that, in fairness, my claim should be put on record, for although it makes very little difference to the world in general who first works out a discovery, yet to the individual whose only gain is the consciousness of having done it, the matter is quite a different thing.

Parsonstown, Ireland, March 9

THOMAS WOODS

\section{The Origin cf Man}

SEEING that the doctrine of evolution has gained ground now almost universally among naturalists, it is surprising that the problem of the origin of man does not raise up an army of investigators, resolved to establish it by "demonstrative evidence" on an unassailable foundation.

It is true that this question has been engaging the attention of naturalists, and that individual explorers have devoted themselves to its solution, but little, if any, united effort has been organiced hitherto. Were the matter taken up with as much earnestness as has been brought to bear on explorations in Assyria cr Palestine, or in the Rocky Mountains of America, it is hard to believe that this question would long remain unsolved.

If the organisation of a society for the purpose of prosecuting research of the kind above indicated were widely agitated, there would not be wanting, I am convinced, either members or funds to further its success. By a strong minited effort-international, if necessary - there is no doubt success wculd be achieved.

We are not utterly without a clue as to the time and place of man's origin. At least such hints as we possess it is our duty to follow up instead of standing by in idle perplexity as to where research should begin.

We now know that it is useless to look for the remains of Simian man in deposits later than pliocene, since the remains of man-not Simian man, but man truly so-called-have been found in pre-glacial and pliocene deposits in the New World as well as in the Old.

The simple fact of the distribution of man over both eastern and western hemispheres having been accomplished as far back as pliocene times, compels us to suppose that man had probably originated not later than the latter part of the miocene age. The discovery of anthropomorpha (Eliopithicus and Dryopithecus) in miocene deposits, while as yet eocene strata have only yieldell lower members of the primates seems to point to miocene times as somewhat near the date of man's origination. So much for our present clue as to Time.

Next as to the Place. Inasmuch as the tertiary formations in the New World have produced hitherto no higher members of the primates than inferior types of monkeys and lemurs, except the recently discovered remains of man himself in pliocene deposits, the inquiry may be confined to the Old World.

In the Old World the most northerly position at which the remains of Anthropomorpha have as yet been found is about the forty-fifth parallel of latitude, namely, in Switzerland and in the south of France.

Now as the higher existing apes are only found in Western Tropical Africa and the Malay Archipelago, while the lower apes (the gibbons) extend into Sonthern China and Northern India. The migration, since miocene times, of the Anthropomorpha, has probably pas:ed along a grand Main Line extending from China through Northern India, Baloochistan, Persia, Asia Minor into the south and south-west of Europe; and from this main line by Tivo Branches: one from Southern China into Malaysia, the other from the region of the Caucasus through Syria, and perhaps Arabia into Africa. 